\title{
THE DISLOCATION UNPINNING FROM STOPPERS IN KBr SINGLE CRYSTALS CAUSED BY ELASTIC STRESSES AND TEMPERATURE
}

\author{
O.M. Petchenko ${ }^{1}$, G.O. Petchenko ${ }^{I}$, S.M. Boiko ${ }^{2}$, A.S. Litvinenko ${ }^{I}$, O.Yu. Kolyada ${ }^{I}$ \\ ${ }^{1}$ O.M. Beketov Kharkiv National University of Urban Economy, Kharkiv, Ukraine \\ E-mail: gdaeron@ukr.net; \\ ${ }^{2}$ M.Ye. Zhukovskiy Kharkiv National Aerospace University, Kharkiv, Ukraine \\ E-mail: svitlanazagreba7@gmail.com
}

The impulse echo-method was applied to study, in the temperature range $300 \ldots 435 \mathrm{~K}$ and at $7.5 \mathrm{MHz}$ frequency, the dislocation attenuation $\alpha_{d}(\sigma)$ in $\mathrm{KBr}$ crystals as a function of static loading in the quasi-elastic strain range. It has been found that the temperature increase at stresses $\sigma<\sigma_{y}\left(\sigma_{y}\right.$ is the yield limit of a crystal) leads to the intensive dislocations' unpinning. Consequently, concentration of stoppers, controlling their motion, sharply decreases and the effective length of oscillating dislocation segments increases. As a result of experimental data processing the energy of the impurity atom binding with dislocation $U_{0}$ was calculated in the following work.

\section{INTRODUCTION}

The study [1], offering a theory for conducting thermal activation analysis of the dislocation unpinning from pinning centers, is based on the results of acoustic measurements. These measurements were obtained under the simultaneous influence of temperature and stresses applied to samples in the elastic strain range. To test this theory [1], authors studied the ultrasonic attenuation $\alpha_{d}$ in high-purity copper samples at a frequency of $10.17 \mathrm{MHz}$ under the influence of thermomechanical effects mentioned above. As a result, the temperature dependence of dislocation segment's average length

$\ell(T)$ was determined here (as well as an average size of dislocation cell $\mathrm{L}$ and the binding energy of impurity atom). Having analyzed the obtained data and chemical composition of studied samples, authors [1] have made a conclusion that atoms of $\mathrm{Fe}$ and $\mathrm{Zn}$ are the most probable centers of dislocation pinning. Noted that previously thermal activation analysis was conducted basing on data obtained by measuring individual dislocation mobility $[2,3]$ or by applying the low-frequency internal friction at $\mathrm{KHz}$ frequency range $[4,5]$. But obtained data were always unreliable. The method's [2,3] errors occur due to difficulties in the calculation of the stress that effects the passage of individual dislocation on $\sim 50$ inter-atomic spacing in crystal when individual dislocation is under the alternate influence of direct and reverse mechanical impulse. Errors in the second method $[4,5]$, which take place due to changes in dislocation structure of the crystal and caused by the influence of elastic waves of considerable amplitude, are not taken into consideration. All this leads to the distortion of observed thermal activation processes' data. In this connection for solving such problems the urgency of the method of high-frequency amplitude independent internal friction is obvious [6-45]. According to this method [1] the sounding pulse with deformation amplitude in sound wave $\varepsilon \sim 10^{-7}$ is passed through the crystal under the external thermomechanical effects. The acoustic signal allows obtaining the high accuracy information on subtle processes in crystals at their loading in the field of quasi-elastic deformation, and this does not affect the course of their occurrence. Due to certain technical difficulties associated with its implementation, the method [1] has not received wide application, although the topicality of its use to study the power laws of dislocations' with stoppers interaction [7], of course, remains relevant.

The purpose of this study is to continue investigations similar to $[1,18]$ on the $\mathrm{KBr}$ crystals.

\section{MATERIALS AND EXPERIMENTAL TECHNIQUES}

In this study, as well as in $[1,18]$, the dislocation ultrasonic $\alpha_{d}$ absorption in $\mathrm{KBr}$ single crystals was studied as a function of the statistic loading value of $\sigma$ in $300 \ldots 435 \mathrm{~K}$ temperature range. The value of $\alpha_{d}$ was measured by the superimposed exponent method on 7.5 MHz longitudinal wave. $\mathrm{KBr}$ crystal was chosen as the object of the study due to its low Debye temperature $(\theta \approx 175 \mathrm{~K})$, which made it possible to observe the effects of the breakout of dislocations at a sufficiently low temperature tests. The samples with orientation $<100\rangle$ were treated by grinding and polishing to achieve the certain non-parallelism of the work surfaces of about $\pm 1 \mu \mathrm{m} / \mathrm{cm}$. Then the prepared samples were annealed in the muffle furnace MP-2UM for $\sim 15 \mathrm{~h}$ at temperature of $600{ }^{\circ} \mathrm{C}$ with subsequent slow cooling up to the room temperature. High-temperature liquid VKJ-94 was applied as a transition layer between the piezoelectric transducer and the sample. Experiments were carried out by the following scheme. Using a specially designed furnace with electronic control a given test temperature of the samples was set and strictly maintained. The temperature was measured with a differential copperconstantan thermocouple. After reaching the required temperature an initial attenuation $\alpha_{0}$ at $\sigma=0$ was measured. Then the sample was step-by-step loaded by compression in the tensile-testing machine of "Instron" type at strain rate of $\sim 3 \cdot 10^{-5} \mathrm{~s}^{-1}$ in the range of stresses $\sigma=(0 \ldots 8) \cdot 10^{5} \mathrm{~Pa}$. To avoid the point defect redistribution under applied load action the time of each loading was $\sim 15 \mathrm{~s}$. After each stop of the machine rod the quantities $\alpha_{d}$ and $\sigma$ were measured. The sample was unloaded when the indicated loading range was over. It was found that after the sample unloading the quantity $\alpha_{d}$ returned to its initial value at the given temperature that evidence on the elastic character of the sample loading. 
This has been confirmed by absence of strain stress on the chart of the recorder KSP-4 at each stop of machine movable clamps in the indicated range of temperatures and stresses. The corresponding estimates were carried out to exclude apparent losses as well as losses caused by the non-parallelism of the working surfaces of the sample from the measured ultrasound attenuation [21]. Analysis has shown that the dominant contribution in the apparent loss is made by the diffraction loss $\alpha_{\text {theor }}=$ $0.104 \mathrm{Db} / \mu \mathrm{m}$.

\section{RESULTS AND DISCUSSION}

The theory [1] is based on the expression [40] $W(\sigma, T) \approx N \cdot \exp \left(-\frac{U(\sigma, T)}{k T}\right)$ for probability $W$ of dislocation segment unpinning from one of point stoppers of total number $N=L / \ell$ under external static loading. Here $U(\sigma, \mathrm{T})=U_{0}-\Upsilon_{\tau}$ is energy of activation of the dislocation unpinning from the pinning centers; $U_{0}$ is the energy of the dislocation binding with the pinning center in the absence of external stresses; $\tau=\Omega \cdot \sigma$ is the reduced shear stress provoking the dislocation slipping; $\Omega$ is orientation factor taking into account that the reduced shift stress in the slip plane is less than the applied stress; $r=b \cdot d \cdot \ell$ is the activation volume, where $d \sim(1 \ldots 3) b$ is distance of the effective dislocation binding with the stopper; $b$ is the Burger vector. In the approximation of the catastrophic dislocations unpinning from stoppers authors [1] have accepted the relation that takes into account the change of the dislocation segment length when the external stress changes in the form of $\ell(\sigma, T)=L W+\ell(1-W)$.

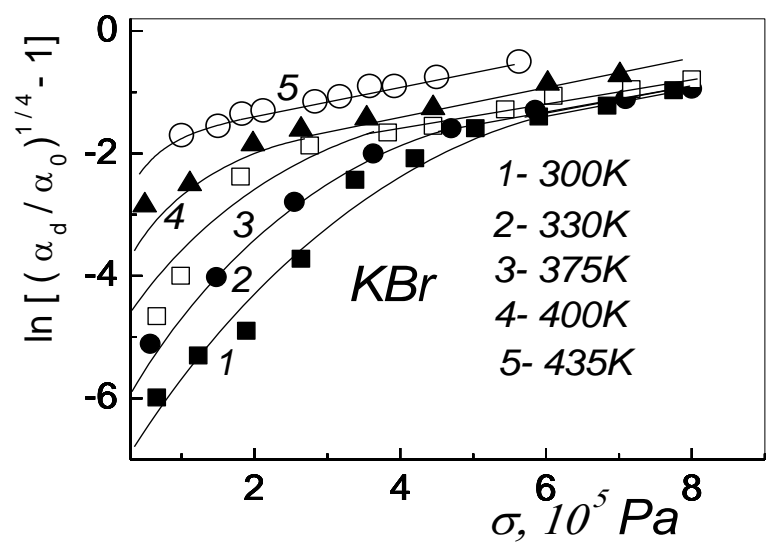

Fig. 1. Reduced dislocation attenuation in $\mathrm{KBr}$ single crystals as a function of external static loading

Taking into account that $\alpha \sim \ell^{4}[21,40]$ the relation is used for low frequencies $\left(\frac{\alpha_{d}(\sigma)}{\alpha_{0}}\right)^{\frac{1}{4}} \approx \frac{\ell(\sigma)}{\ell}$, where $\alpha_{0}=\alpha_{d}(\sigma=0)$. The resulting relation, appropriate for thermal activated analysis based on experiment data, looks like [1]:

$$
\ln \left[\left(\frac{\alpha_{d}}{\alpha_{0}}\right)^{\frac{1}{4}}-1\right] \approx \ln \frac{L^{2}}{\ell^{2}}-\frac{U_{0}}{k \cdot T}+\frac{\Omega \cdot b \cdot d \cdot \ell \cdot \sigma}{k \cdot T} .
$$

Experimental dependences $\ln \left[\left(\frac{\alpha_{d}}{\alpha_{0}}\right)^{\frac{1}{4}}-1\right]-\sigma$, obtained in our study at temperatures 300, 330, 375, 400, and $435 \mathrm{~K}$ are presented in Fig. 1.

According to [1] in each of the curves 1-5 (see Fig. 1) after reaching the stress $\sigma^{*}$ the linear sections appear from which the dependence of the dislocation segment length $\ell(T)$ can be reproduced by the formula:

$$
\ell=\frac{k \cdot T \cdot \Delta \ln \left[\left(\frac{\alpha_{d}}{\alpha_{0}}\right)^{\frac{1}{4}}-1\right]}{\Omega \cdot b \cdot \ell \cdot \Delta \sigma} .
$$

Using the data given in Fig. 1 and other values $(\Omega$, $b$ ) taken from our paper [15], this dependence was obtained (Fig. 2, curve 1).

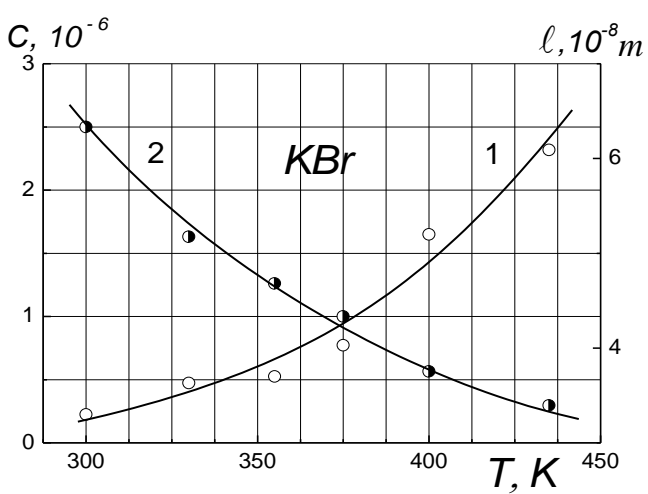

Fig. 2. The temperature dependence of the effective length of the dislocation segment 1 and impurity concentration of dislocation 2 in $\mathrm{KBr}$ single crystals

It is evident that $\ell(T)$ increases with the temperature increasing and, taking into account equation (1), the dislocation ultrasound attenuation $\alpha_{d}$ should increase too; this is observed in our experiments.

Very likely, that the dislocation segment length $\ell$ increasing with temperature is related with gradual decrease of the pinning center concentration $C$ on the dislocations. It is convenient to verify such as assumption with the use of the expression from $[1,18]$ :

$$
C=\frac{b \cdot \sigma_{k p}}{28 \cdot k \cdot T \cdot \ell \cdot N_{0}},
$$

where $N_{0}=\frac{8}{a^{3}}$, is the lattice constant [15]. As well as, the results for $\ell(T)$, dependence $C(T)$ were obtained (see Fig. 2, curve 2).

It is obvious, that the temperature increase promotes the processes of dislocation separation from the stoppers that leads to the concentration $C(T)$ decrease and, subsequently, to $\ell(T)$ increase. Using equation [1]:

$$
C \approx\left(\frac{\beta_{a}}{\beta_{m}}\right) \cdot C_{0} \cdot \exp \left(\frac{U_{0}-T\left(S_{m}-S_{a}\right)}{k T}\right),
$$

where $\beta_{a}$ and $\beta_{m}$ are the numbers of equivalent free positions of interstitials or substitutions in the unit cell of the dislocation atmosphere; $C_{0}-$ atomic fraction of impurity atoms in the matrix volume; $S_{a}$ and $S_{m}$ - oscillatory entropies of matrix atoms and dislocation atmosphere it is easy to find the energy of dislocation binding with 
the pinning center. By taking the logarithm of equation (3) we obtain

$$
\ln C \approx \ln \left[\left(\frac{\beta_{a}}{\beta_{m}}\right) \cdot C_{0}\right]-\frac{\left(S_{m}-S_{a}\right)}{k}+\frac{U_{0}}{k T} .
$$

It is seen from the equation [4] that by plotting the dependence $\ln C-f(1 / T)$ it is easy to determine $U_{0}$ by the slope.

Fig. 3 presents the dependence $\ln C-(1 / T)$ calculated with taking into account the curve $C(T)$.

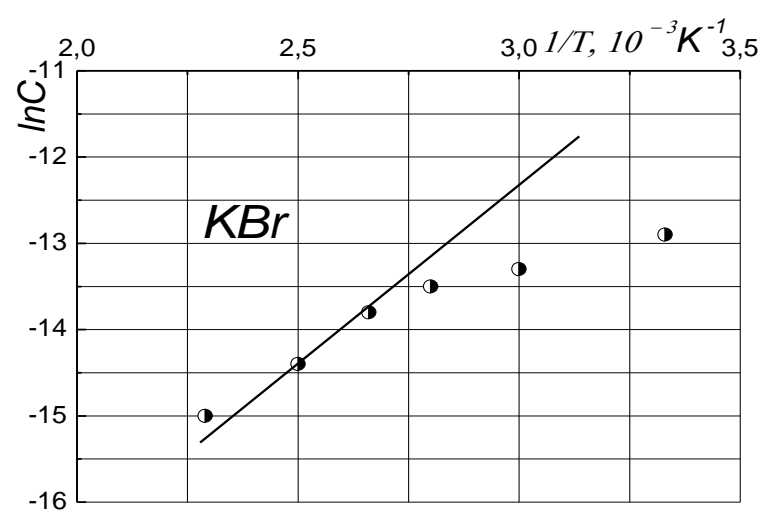

Fig. 3. Temperature dependence of pinning centers concentration in $\mathrm{KBr}$ single crystals

According to recommendations of [1] by plotting the linear dependence we oriented ourselves onto the points related to the high-temperature regions where the mechanisms of dislocation thermal unpinning from the impurity atoms prevail over purely mechanical separation. After determination of the temperature behavior of the indicated line we have found the value of the energy of dislocation binding with stoppers $U_{0} \sim 0.37 \mathrm{eV}$ that is in good agreement with the results of $[1,18]$.

\section{CONCLUSIONS}

The acoustic impulse method was applied to investigate, in the temperature range from 300 to $435 \mathrm{~K}$ and at 7.5 $\mathrm{MHz}$ frequency, the dislocation absorption $\alpha_{d}(\sigma)$ in $\mathrm{KBr}$ crystals as a function of the statistic load in the quasi-elastic strain range. It has been found that at $T=300 \mathrm{~K}$ the loading change has a weak effect on the quantity $\alpha_{d}$ increase. However, after the rise in temperature the same loads lead to significant acoustic loss increasing. As a result of experimental data processing within the framework of known theories, the temperature dependences of the dislocation segment length $\ell(T)$ and the of point pinning center concentration on dislocations $C(T)$ were determined. It is shown that the temperature increase under the stresses $\sigma<\sigma_{y}\left(\sigma_{y}\right.$ denote the yield limit of a crystal) leads to the intensive dislocation unpinning. Consequently, the concentration of stoppers controlling the dislocation motion sharply decreases and the effective length of oscillating dislocation segments increases. The value of the energy of impurity atom binding with a dislocation is calculated, which equals $U_{0} \sim 0.37 \mathrm{eV}$ for $\mathrm{KBr}$ crystal. Analysis has shown that the values of mentioned dislocation characteristics are in close agreement with theoretical estimates, as well as, with experimental data obtained by the same method for ion crystals $\mathrm{CsJ}$ and $\mathrm{KCl}$.

\section{REFERENCES}

1. M.A. Krishtal, S.A. Golovin, I.V. Troitskij. Study of the parameters of the dislocation structure of copper by the ultra-sound pulse method // Phys. Metals and Metal Science. 1973, v. 35, N 3, p. 632-639.

2. V.I. Startsev, V.Ya. Ilyichev, V.V. Pustovalov. Plasticity and strength of metals and alloys at low temperatures. M.: "Metallurgiya", 1975, $328 \mathrm{c}$.

3. V.M. Chernov. Mobility of dislocations in crystals with centers of pinning // FTT. 1973, v. 15, N 4, p. 1159-1166.

4. S.P. Nikanorov, B.K. Kardashov. Elasticity and Dislocation Inelasticity of Crystals. M.: "Nauka", 1985, $256 \mathrm{p}$.

5. M.A. Krishtal, S.A. Golovin. Internal friction and metal structure. M.: "Metalurgia", 1976, 375 p.

6. G.O. Petchenko, O.M. Petchenko. Research of the elastic wave velocity dispersion in X-ray-irradiated LiF crystals // Ukrainian journal of physics. 2013, v. 58, N 10, p. 974-979.

7. G.A. Petchenko. Research of the preliminary deformation and irradiation effect on the viscous damping of dislocation in LiF crystals // Functional Materials. 2013, v. 20, N 3, p. 315-320.

8. G.O. Petchenko. Acoustic studies of the effect of $\mathrm{X}$-ray irradiation on the dynamic drag of dislocations in LiF crystals / G.O. Petchenko // Ukrainian journal of physics. 2011, v. 56, N 4, p. 339-343.

9. G.A. Petchenko. The investigation of the dislocations resonance losses of ultrasonic sound in irradiated LiF single crystals in the interval of irradiation doses 0...400 R // Problems of Atomic Science and Technology. 2012, N 2(78), p. 36-39.

10. G.A. Petchenko, A.M. Petchenko. The study of the dislocation resonance in LiF crystals under the influence of the low-dose X-irradiation // Functional Materials. 2010, v. 17, N 4, p. 421-424.

11. G.A. Petchenko. Study of dynamic and structural characteristics in irradiated LiF crystals // Problems of Atomic Science and Technology. 2013, N 2(84), p. 55-59.

12. G.A. Petchenko. Dynamic damping of dislocations in the irradiated LiF crystals // Functional Materials. 2012, v. 19, N 4, p. 473-477.

13. O.M. Petchenko, G.O. Petchenko. Phonon drag of dislocations in $\mathrm{KCl}$ crystals with various dislocation structure states // Ukrainian journal of physics. 2010, v. 55, N 6, p. 716-721.

14. A.M. Petchenko, G.A. Petchenko. Features of resonance absorption of longitudinal ultrasound in strained crystals $\mathrm{KBr}$ at temperature variations // Functional Materials. 2007, v. 14, N 4, p. 475-479.

15. V.P. Matsokin, G.A. Petchenko. Viscous dislocation drag in $\mathrm{KBr}$ crystals at 77-300 K // Fizika Nizkikh Temperatur. 2000, v. 26, N 7, p. 705-710 (in Russian).

16. G.O. Petchenko, O.M. Petchenko, S.M. Boiko. The investigation of X-ray irradiation on elastic, dynamical and structural characteristics of strained LiF crystals // Problems of Atomic Science and Technology. 2018, N 2(114), p. 25-28. 
17. G.O. Petchenko, O.M. Petchenko, S.M. Boiko. The investigation of X-ray irradiation effect on the mobility of dislocations in LiF crystals // Problems of Atomic Science and Technology. 2018, N 5(117), p. 1620.

18. G.A. Petchenko, A.M. Petchenko. Influence of elastic stresses and temperature on the dislocation unpinning from the stoppers in $\mathrm{KCl}$ crystals // Functional Materials. 2015, N 3, p. 293-298.

19. G.A. Petchenko, S.S. Ovchinnikov. Effect of the preliminary deformation and irradiation on the optical absorption in LiF crystals // Problems of Atomic Science and Technology. 2014, N 2(90), p. 29-33.

20. G.A. Petchenko, A.M. Petchenko. Dependence of electronic color center concentration on the state of irra-diated LiF crystal dislocation structure // Problems of Atomic Science and Technology. 2015, N 2(96), p. 25-28.

21. R. Truell, Ch. Elbaum, B. Chik. Ultrasound methods in solid state physics. M.: "Mir", 1972, 307 p.

22. V.S. Postnikov. Inernal friction in metals. M. "Metalurgia", 1969, 330 p.

23. T. Suzuki, A. Ikushima, M. Aoki. Acoustic attenuation studies of the frictional force on a fast moving dislocation // Acta met. 1964, v. 12, N 11, p. 1231-1240.

24. L.G. Merculov. Absorption of ultrasonic waves in some alkali halide crystals // Acoustic journal. 1959, v. $5, \mathrm{~N} 4$, p. $432-439$.

25. L.G. Merculov, L.A. Yakovlev. Ultrasound studies of deformed $\mathrm{NaCl}$ crystals // Acoustic journal. 1960, v. 6, N 2, p. 244-251.

26. L.G. Merculov, R.V. Kovalionok, E.V. Konovodchenko. Temperature dependence of the absorption of ultrasonic waves in $\mathrm{NaCl}$ crystals // FTT. 1971, v. 13, N 4, p. 1171-1177.

27. Kh.M. Khalilov, A.I. Agaev. Ultrasound absorption in $\mathrm{KCl}$ single crystals in the megahertz frequency range // Izv. AN Azerbajdg. SSR. 1966, N 2 , p. $82-86$.

28. Kh.M. Khalilov, A.I. Agaev. Dislocation absorption of ultrasound in deformed $\mathrm{KCl}$ crystals // FTT. 1971, v. 9, N 9, p. 2729-2731.

29. N.P. Kobelev, Y.M. Soifer, V.I. Alshits. The relation between viscous and relaxation components of dislocation damping of the high-frequency ultrasound in the copper // FTT. 1979, N 4(21), p. 1172-1179.

30. L.A. Yakovlev. Investigation of the frequency and amplitude dependences of the dislocation absorp- tion of ultrasound in aluminum // Acoustic journal. 1965. v. XI, N 2, p. 239-242.

31. Yu.F. Boiko, S.V. Lubenets, L.S. Fomenko, N.M. Fedirenko. About study of dynamic properties of dislocations by the shock loading sample method // I $z v$. Vyzov. Fizika. 1978, N 7, p. 129-131 (in Russian).

32. V.I. Alshits, V.L. Indenbom. Dynamic drag of dislocations // Usp. Fiz. Nauk. 1975, v. 115, N 3, p. 3-39 (in Russian).

33. V.I. Alshits. "Phonon wind" and dislocation drag // FTT. 1969, v. 11, N 8, p. 2405-2407.

34. E.V. Korovkin, Ya.M. Soifer. The effect of dislocations on the attenuation of ultrasound in $\mathrm{NaCl}$ crystals // FTT. 1971, v. 13, N 12, p. 3709-3710.

35. N.P. Kobelev, Ya.M. Soifer. Viscous drag of dislocations in alkali halide crystals // FTT. 1976, v. 18, N 4, p. 1073-1076.

36. F. Fanti, J. Holder, A.V. Granato. Viscous drag on dislocation in $\mathrm{LiF}$ and $\mathrm{NaCl} / /$ J. Acoust. Soc. Amer. 1969, v. 45, N 6, p. 1356-1366.

37. A. Hikata, J. Deputat, C. Elbaum. Dislocation interactions with phonons in sodium chloride in the temperature range 77-300 K // Phys. Rev. 1972, v. 6, N 10, p. 4008-4013.

38. A. Hicata, B. Chick, C. Elbaum, R. Truell. Dislocation damping in sodium chloride // Appl. Phys. Let. 1963, v. 2, N 1, p. 5-6.

39. P. Pal-Val, V. Platkov, V. Startsev. Temperature dependence of the dislocation drag constant in antimony // Phys. stat. sol. 1976, v. 38, p. 383-391.

40. A. Granato, K. Lücke. String model of dislocation and dislocation ultrasound absorption. Physical acoustic. M.: "Mir", 1969, v. 4, P. A, p. 261-321.

41. H. Koizumi, I. Iwasa, M. Kakumoto, T. Suzuki. Study of dislocations in CsJ by simultaneous measurements of ultrasonic velocity and attenuation // $J$. Journ. of Appl. Phys. 1986, v. 25, p. 52-54.

42. O.M.M. Mitchel. Drag of dislocation in LiF // J. Appl. Phys. 1965, v. 36, N 12, p. 2083-2084.

43. A.A. Botaki, A.A. Vorobev, V.A. Ulyanov. Radiation physics of ionic crystals. M.: "Atomizdat", 1980, 208 p.

44. R.M. Stern, A. Granato. Damped dislocation resonance in copper. Internal friction and defects in metals. M.: "Metallurgiya", 1965, p. 149-191.

45. T. Kaneda. Frictional force on a fast moving dislocation in cooper and its dilute allows // $J$. of the Phys. Soc. of Japan. 1970, v. 28, N 5, p. 1205-1211.

\section{ОТКРЕПЛЕНИЕ ДИСЛОКАЦИЙ ОТ СТОПОРОВ В МОНОКРИСТАЛЛАХ КВr, ВЫЗВАННОЕ УПРУГИМ НАПРЯЖЕНИЕМ И ТЕМПЕРАТУРОЙ}

\section{А.М. Петченко, Г.А. Петченко, С.Н. Бойко, А.С. Литвиненко, О.Ю. Коляда}

С помощью импульсного эхо-метода на частоте 7,5 МГц в температурном интервале $300 . .435$ К изучено дислокационное затухание ультразвука $\alpha_{d}(\sigma)$ в $\mathrm{KBr}$ как функция статического напряжения в квазиупругой области деформаций. Определено, что повышение температуры при величинах $\sigma<\sigma_{y}\left(\sigma_{y}-\right.$ предел текучести кристаллов) приводит к интенсивному откреплению дислокаций. Из-за этого концентрация стопоров, ограничивающих их движение, резко снижается, а эффективная длина дислокационного сегмента увеличивается. Путем обработки экспериментальных результатов рассчитана величина энергии связи $U_{0}$ примесного атома с дислокацией. 


\section{ВІДКРІПЛЕННЯ ДИСЛОКАЦІЙ ВІД СТОПОРІВ У МОНОКРИСТАЛАХ КВr, ВИКЛИКАНЕ ПРУЖНИМ НАВАНТАЖЕННЯМ I ТЕМПЕРАТУРОЮ}

\section{О.М. Петченко, Г.О. Петченко, С.М. Бойко, А.С. Литвиненко, О.Ю. Коляда}

За допомогою імпульсного ехо-методу на частоті 7,5 МГц у температурному інтервалі $300 \ldots 435 \mathrm{~K}$ вивчено дислокаційне згасання ультразвуку $\alpha_{d}(\sigma)$ у $\mathrm{KBr}$ як функція статичного навантаження в квазіпружній області деформацій. Визначено, що підвищення температури при величинах $\sigma<\sigma_{y}\left(\sigma_{y}-\right.$ границя плину кристалів) призводить до інтенсивного відкріплення дислокацій. Внаслідок цього концентрація стопорів, що контролюють їх рух, різко знижується, а ефективна довжина дислокаційного сегмента збільшується. Шляхом обробки експериментальних результатів розраховано величину енергії зв'язку $U_{0}$ домішкового атома 3 дислокацією. 